is in a position to bear the whole of their cost. At the same time it is considered that if an industry can produce a practicable scheme, Government assistance in obtaining Parliamentary powers for a compulsory levy should be forthcoming. We hope to discuss this Report in more detail in due course.

\section{Liebig and Faraday at York}

IT is one of the benefits of international intercourse that visitors to a country often record in their letters and diaries their impressions and memories of men and institutions, for which we cannot be too grateful. From these records we get those glimpses of the past which often escape the historian. Thus from the memoirs of Bishop Taylor of Norwich we can picture the aged Haüy - who looked like a man picked out of a crystal-lecturing at the Jardin des Plantes, where, " as everywhere also, the utmost liberty is shown to all, but to Englishmen particularly your country is your passport" ; while from the letters of Helmholtz we see Tait "a particular form of savage" at St. Andrews, where, devoted to golf, he could only be brought to talk of rational matters on a Sunday. Of all the men of science who visited England in the early days of Victoria, none was better known than Liebig, who was at York for the 1844 meeting of the British Association, and afterwards toured Great Britain in the company of Playfair, Daubeny, and Dean Buckland. After his return to Giessen, Liebig wrote a charming letter to Faraday, which was long treasured by the late George B. Buckton, and which through the kindness of Miss A. M. Buckton was published in full in the Times on Aug. 31. During this year's meeting of the British Association the letter has been on exhibition, and Miss Buckton proposes to send it to General Smuts, as a contribution to the newly built Witwatersrand Library. It is stated in the Times that the letter has hitherto been unpublished, but perhaps it should be pointed out that it was printed in W. A. Shenstone's "Justus von Liebig, his Life and Work", published by Messrs. Cassell and Co. in 1901. While Liebig's letter contains an interesting view of British science at the time, Frank Buckland has left us an equally interesting contemporary account of the happy sarroundings in which Liebig lived and worked at Giessen.

\section{Founders of the Royal College of Chemistry}

THE memory of Liebig is also revived by an article, accompanied by a reproduction of a daguerreotype of five of his assistants, contemporaries in his laboratory at the University of Giessen, all of whom were pioneers of chemistry, which appears in the Times of Sept. 5. Three were German-Hofmann, Fresenius, and Will-and two were English-Gardner and Bullock, who were associated in 1845 in the foundation of the Royal College of Chemistry, of which Dr. Gardner was secretary and Hofmann the first professor of chemistry. That three of the chemists associated with the Royal College of Chemistry in its early days should be included in a single photograph will be of special interest to past and present students of the Royal College of Science, its lineal descendant. "Ninety years ago", says the writer of the article, explaining the picture, "five young men met for a solemn function. . . . They met to be photographed." He gives a list of the distinguished chemists trained by Hofmann at the College, of whom Prof. H. E. Armstrong survives.

\section{The Chinese Earthquake of Aug. 14}

AN earthquake of considerable severity occurred in the south-west of China at about noon (Chinese time) on Aug. 14, and was registered by seismographs throughout the world. From the records at six abservatories, the officials of the U.S. Coast and Geodetic Survey place the epicentre in about lat. $27^{\circ} \mathrm{N}$., long. $103^{\circ} \mathrm{E}$. (Wire Report of Science Service, Washington, D.C., Aug. 16). This point lies near the northern boundary of the province of Yunnan, about seven hundred miles to the south of the province of Kansu, in which the destructive earthquakes of 1920 and 1927 occurred. Kansu is a thickly populated. province, and it is possible that some thousands of lives may have been lost, though weeks may elapse before news reaches us from the central district. From the beginning of the sixteenth century, it has been visited by twenty disastrous earthquakes, by one of the latest of which, in 1888, about five thousand persons were killed. According to Mr. N. F. Drake (Amer. Seis. Snc. Bull., vol. 2, pp. 40.91; 1912), the province of Yunnan is one of the most important earthquake districts of China. He represents the relative seismicities of the four principal districtsFukien, Kansu, Chihli, and Yunnan-by the numbers $100,98,94$, and 91 .

\section{The Rubber Industry in Malaya}

THE rubber industry of Malaya is passing through the most critical period which it has yet experienced, so that the issue of a special rubber number of the Malayan Agricultural Journal (vol. 20, part 5) is of particular interest. The recent decision against compulsory restriction of rubber growing, though a disappointment to many, has, by removing the element of uncertainty, enabled the estates to frame their policy more clearly. Under-consumption rather than over-production is the cause of the present crisis, so that it is hoped to rectify matters by more intensive production on areas actually in tapping, and by im. proving the liaison between the scientific investigator and both producer and consumer. Already great reductions have been effected in the cost of production. Factory improvements, such as the construction and installation of batteries of light sheeting machines in cascade or file formation instead of in line, have facilitated and accelerated the handling of the coagulum, and more rapid methods of drying and smoking have been evolved. Economy has also resulted by the use of treated hessian for packing in place of the usual wooden chests. Considerable increase in the export of latex continues, and the extended application of this form of product to new uses is a hope. ful sign of development on at least one side of the in. dustry. Every effort is being made to study the best methods for growing and manuring the crop and for controlling the various diseases and insect pests which attack the rubber plant, so that when the industry

No. 3280, VoL. 130] 